\title{
Molecular Dynamic Simulations to Understand the Hydrothermal Deposits of Rare Earth Elements
}

\author{
QIUSHI GUAN ${ }^{1,2}$, YUAN MEI $^{1}$, BARBARA ETSCHMANN ${ }^{2}$, \\ MARION LOUVEL ${ }^{3}$ AND JOËL BRUGGER ${ }^{2}$ \\ ${ }^{1} \mathrm{CSIRO}$ \\ ${ }^{2}$ Monash University \\ ${ }^{3}$ WWU Munster \\ Presenting Author: qiushi.guan@monash.edu
}

Rare earth elements (REE) have attracted increasing attention due to their applications in industry, but the production of REE are restricted to only a few locations. REE deposits generally form from a combination of magmatic and hydrothermal processes. A quantitative understanding of REE behaviour in hydrothermal solutions is important not only to understand the processes of REE concentration, but also to improve their utility as petrogenetic indicators. The mobilization of REE in hot fluids relies on which complex the REE form with available ligands, and the relative stability of these complexes. However, much of this information remains unknown or disputed, especially under high pressure $(\mathrm{P})$ and temperature $(\mathrm{T})$ conditions typical for the formation of high grade REE deposits associated with carbonatites and agpaitic magmatism.

Ab initio molecular dynamic simulations (MD) are an effective method to predict metal complexes and their thermodynamic properties[1] and offer the opportunity to achieve conditions that cannot be reached via the experimental approach. Our group has obtained new properties for the $\mathrm{Y}(\mathrm{III})-\mathrm{Cl}^{-}[2], \mathrm{Y}(\mathrm{III})-\mathrm{SO}_{4}{ }^{2-}$ and $\mathrm{La}(\mathrm{III})-\mathrm{Cl}^{-}$complexes at temperature up to $500{ }^{\circ} \mathrm{C}, 600$ to 1000 bar via MD studies. The predicted geometries are supported by in-situ XAS measurements conducted over similar P-T-X range. The data produced by MD will allow accurate modelling of REE transport in ore-forming process.

\section{References}

1. Brugger, Liu, Etschmann, Mei, Sherman and Testemale (2016), Chemical Geology 447, 219-253.

2. Guan, Mei, Etschmann, Testemale, Louvel and Brugger (2020), Geochimica et Cosmochimica Acta 281, 168-189 